medical men; and frcquently, in a criminal trial, the medical witness is of more real importance and ntility than judge, barrister, and jury put together.

Allow me to elucidate these general remarks by some facts taken from my own experience: and first, with regard to the remuneration; secondly, the treatment.

First. Some years ago I was sent for to make a post-mortem of a man named Hornsby, who had died at Haltwhistle, in Northumberland, about forty miles from Newcastle, under suspicion of having been poisoned. I found the post-mortem results confirmatory of these suspicions; I then made an analysis of the viscera, qualitative and quantitative, for arsenic, which $I$ detected and determined. I was again sent for to Haltwhistle, to give evidence before the magistrates, and again to attend an adjourned inquest. I consider that my remuneration for this work should have been, under a proper system, at least,- -

For three visits to Halt whistle, (in all 240 )

miles) attendance, and expenses $\quad \ldots\}\left\{\begin{array}{llll}£ 18 & 18 & 0\end{array}\right.$

$\begin{array}{lllllllll}\text { For analysis, \&c. } & \ldots & \ldots & \ldots & \ldots & \ldots & 15 & 15 & 0\end{array}$

$$
\$ 3413 \quad 0
$$

The coroner, Mr. Reed, showed every desire to do me some justice, and allowed me the fee of twenty guineas, which letters from Professor Christison, Professor Taylor, Dr. Brett, of Liverpool, and Professor Johnston, stated was a very moderate charge; but the county magistrates refused to allow more than the legal fee of two guineas, which would not more than half defray my travelling expenses!

I was so indignant that I contemplated bolting from York assizes, where I had to attend a civil case, among the Yorkshire hills, with my fishing-rod, leaving the woman accused to be tried at Newcastle without me, in order to protest thus against such monstrous injustice; and $I$ should most certainly have done so could I have afforded to pay the heavy fine that would most likely have been inflicted. After the trial the matter was brought by the solicitors in the case (Messrs. Carrick and Lee, of Brampton, who were most anxious to do me justice) before the judge, (Wiglitman,) who, in the most handsome manner, ordered the county to pay me twenty guiners, in addition to three guineas for attendance before the magistrates at Hartwhistle, four guineas for attending the court, and two guineas for the inquest, so that $I$ received twenty-nine guineas. The same judge, I may mention, in another trial, acted to me in a similar way, and did it with compliments.

But suppose the case had not come to a trial, or that the judge had not been a man of the same just and liberal mode of thinking: I should have been mulcted of skill, time, and money, for the benefit of the public.

In a recent case $I$ had to make an analysis of the most difficult kind; literally to stew down half a body, as Orfila in the case of Laffiarge, to get a result, and to attend at Sedge. field, thirty miles off. There the coroner got me a fee of ten guineas, but the law would have only allowed two guineas. I have corresponded with other medical men who are often engaged in such cases, and find them all complain bitterly of the inadequate and uncertain remuneration.

But Judge Martin says we are entitled to none at all for our professional services in courts of justice! Was there ever anything so monstrous?

Secondly. Another thing of which the profession has too often to complain, is the grossly uncivil trealment we so often meet with. By the way, perhaps Judge Martin may not recollect an arbitration case at Newcastle, where the writer of this letter was asked by a Mr. Martin, whether he "would give a horse a pounded paving-stone in its water to drink ?" and the answer, "No, Sir; nor ask such a foolish question!" I was once examined by a barrister, who absolutely acted a deliberate falsebood, in order to induce me to hesitate in my evidence. He was cross-examining from Taylor's "Medical Jurisprudence;" and asked if the precipitates yielded by sulphuretted hydrogen with salts of antimony and tin could be distinguished from that furnished by arsenic. I said "Yes." He looked for some time at the book, and as if he pretended to find there what he did not find, said, in a triumphant tone-" "Do you still mean, Sir, to tell me that!" Answer, "Yes!"

I was informed some time ago, that a judge asked an eminent physician, who was a witness against a quack then being tried for manslaughter, and who had refused to meet this quack in that very case, why he would not go? - "Because it was contrary to medical etiquette." "What do you mean, Sir, by medical etiquette?" The answer should have been"Why, there is ax etiquette even in your profession!" I should have added, that the quack was of course acquitted; and on his return to the place where the atrocity for which he was tried had been perpetrated, carried, I believe, in a triumphal procession.

We never go into court as hired sophisticators, or arrogant bullies or the calumniators of innocence and defenders of guilt; but as the witnesses and real ministers of science, truth, and justice.

In conclusion, I hope that the profession will as one man, petition Parliament, to regulate on a prover scale the fees to which we are entitled for our services in cases of legal medicine. Travelling expenses should be provided for, and at least five guineas a day for attendance in court. Chemical analyses should be paid for still more handsomely in criminal than in civil cases. Fees of ten, twenty, or thirty guineas should be allowed, instead of the sum of two guineas. In civil cases we can generally make our own bargain; and people will pay much more freely for the defence of their property than the protection of their health, and the saving of their lives.
Newcastle, Apri15, 1851. Your obedient servant, R. M. GLover.

\section{THE ANALYTICAL SANITARY COMMISSION.} MIUSTARD.

To the Editor of The Latcet.

Sir,-I noticed in a late number of Tae Lancer, a statement that genuine mustard was not to be obtained in London, and have found such to be the case. I have been a manufacturer of mustard for twenty years, and during that time have frequently attempted to introduce it to the London trade, but could never succeed. The London mustard is principally made from the white mustard-seed, with the addition of the ingredients mentioned in your analysis. The description of mustard I manufacture is from the brown seed (Sinapis Nigra), of which I take the liberty of sending you a sample. You will find it quite free from the adulterations found in the London mustards. The reason why I could never get it into the London market is, the difference of colour-it being much darker than that made from the white seed; and the brown seed being much dearer and less productive, I have to charge a higher price for it.
Thos. Dewar.

* * Our correspondent is deceived; the article he has sent to us is not a specimen of pure brown mustard, as it contains a small quantity of turmeric.-ED. L.

\section{Antedíal $\mathbf{f}$ teros.}

Royal College of Surgeons.-The following gentlemen, having undergone the necessary examinations for the diploma, were admitted members of the college, at the meeting of the Court of Examiners, on the 11th inst.:-

BakeR, Benjamin, Broadway, Worcestershire.

BrRd, JoHn J J Mres, Market-Rasen, Lincolnshire.

Bywater, John HaLl, Fnottingley, Yorkshire.

Hartshorne, Frederick Hezekiah, Broseley, Salop.

Head, Edwarm Abraham Hancock, Stoke, Plymouth.

Roust, JAMIS, Walham-green.

Rowland, Willitam Jonnson, Wargrave, Berkshire.

Spencen, Thomas, East Shilton, Leicestershire.

Tickell, John Hender, East Looe, Cornwall.

Unptielibx, Eimond, Belstead, Suffolk.

At the same meeting of the Court, Mr. William Ross passed his examination for Naval Surgeon. This gentleman had previously been admitted a member of the College, his diploma bearing date December $23,1844$.

The following members of the institution, having undergone the necessary examinations on Monday and Wednesday last for the Fellowship, were yesterday afternoon admitted by the President and Council, fellows of the College:-

Adams, Wruliam, New Broad-street, diploma dated Feb. 4, 1842 .

Alexander, JAMes, London, November 19, 1841.

Barker, Walter Rioe Howell, Wantage, March 5, 1841.

Butrer, James Henry, Bengal Army, A pril 26, 1839

Ottaway, James Cutheert, Dover, April 19, 1833. 